\title{
Glacier contribution to streamflow in two headwaters of the Huasco River, Dry Andes of Chile
}

\author{
S. Gascoin ${ }^{1, *}$, C. Kinnard ${ }^{1}$, R. Ponce ${ }^{1}$, S. Lhermitte ${ }^{1,{ }^{* *}}$, S. MacDonell ${ }^{1}$, and A. Rabatel ${ }^{2}$ \\ ${ }^{1}$ Centro de Estudios Avanzados en Zonas Áridas (CEAZA), La Serena, Chile \\ ${ }^{2}$ Laboratoire de Glaciologie et Géophysique de l'Environnement (LGGE), 54 rue Molière, \\ 38402 Saint Martin d'Hères cedex, France \\ * now at: Centre d'Études Spatiales de la Biosphère (CESBIO), 18 avenue Belin, bpi 2801, 31401 Toulouse cedex 9, France \\ ** now at: Royal Netherlands Meteorological Institute (KNMI), Wilhelminalaan 10, P.O. Box 20, 3730 AE De Bilt, \\ The Netherlands
}

Received: 28 August 2010 - Published in The Cryosphere Discuss.: 9 November 2010

Revised: 21 November 2011 - Accepted: 22 November 2011 - Published: 2 December 2011

\begin{abstract}
Quantitative assessment of glacier contribution to present-day streamflow is a prerequisite to the anticipation of climate change impact on water resources in the Dry Andes. In this paper we focus on two glaciated headwater catchments of the Huasco Basin (Chile, $29^{\circ} \mathrm{S}$ ). The combination of glacier monitoring data for five glaciers (Toro 1, Toro 2, Esperanza, Guanaco, Estrecho and Ortigas) with five automatic streamflow records at sites with glacier coverage of 0.4 to $11 \%$ allows the estimation of the mean annual glacier contribution to discharge between 2003/2004 and 2007/2008 hydrological years. In addition, direct manual measurements of glacier runoff were conducted in summer at the snouts of four glaciers, which provide the instantaneous contribution of glacier meltwater to stream runoff during summer. The results show that the mean annual glacier contribution to streamflow ranges between 3.3 and $23 \%$, which is greater than the glaciated fraction of the catchments. We argue that glacier contribution is partly enhanced by the effect of snowdrift from the non-glacier area to the glacier surface. Glacier mass loss is evident over the study period, with a mean of $-0.84 \mathrm{~m}$ w.e. $\mathrm{yr}^{-1}$ for the period 2003/2004-2007/2008, and also contributes to increase glacier runoff. An El Niño episode in 2002 resulted in high snow accumulation, modifying the hydrological regime and probably reducing the glacier contribution in favor of seasonal snowmelt during the subsequent 2002/2003 hydrological year. At the hourly timescale, summertime glacier contributions are highly variable in space and time, revealing large differences in effective melting rates between glaciers and glacierets (from $1 \mathrm{~mm}$ w.e. $\mathrm{h}^{-1}$ to $6 \mathrm{~mm}$ w.e. $\mathrm{h}^{-1}$ ).
\end{abstract}

Correspondence to: S. Gascoin (simon.gascoin@ceaza.cl)

\section{Introduction}

Numerous studies have drawn attention to the Andean glaciers, especially in the tropical Andes (e.g., Ramirez et al., 2001; Coudrain et al., 2005; Bradley et al., 2006; Vuille et al., 2008), because their recent accelerated retreat represents a striking example of climate change impacts. Indeed, these glaciers are generally regarded as critical water reserves, and their shrinkage is presented as a real threat to future fresh water supply in the Andean countries. Because of this link, glacier retreat in the Andes is often used to illustrate the implications of the global climatic changes in terms of water resources at the local scale. Furthermore, glacier runoff is a major concern in case that a glacier could be affected by local human activities like mining - in addition to the global climatic change.

However, the contribution of glaciers to the water cycle is not always obvious and few studies have proposed a thorough analysis of their hydrological significance across the Andes Cordillera (Ribstein et al., 1995; Mark and Seltzer, 2003; Favier et al., 2008; Soruco et al., 2009). For example, glacier shrinkage in the Dry Andes region (sensu Lliboutry, 1998, i.e. between $20^{\circ} \mathrm{S}-35^{\circ} \mathrm{S}$ ), has been well described (Leiva, 1999; Rivera et al., 2002; Le Quesne et al., 2009; Rabatel et al., 2011), yet the role of these glaciers in the hydrological cycle is much less documented. This discrepancy might be due to fact that glacial retreat is observable by remote sensing techniques, whereas hydrological balance studies require collecting field data in an environment difficult to access, especially in the Dry Andes, where glaciers occur at altitudes of $3000 \mathrm{~m}$ to nearly $7000 \mathrm{~m}$ a.s.l.

In this paper we examine the glacier contribution to the discharge of two Huasco River headwaters: the Estrecho River and the Potrerillos River $\left(29.3^{\circ} \mathrm{S} ; 70.1^{\circ} \mathrm{W}\right)$. As in many other semi-arid regions in the world, the population of

Published by Copernicus Publications on behalf of the European Geosciences Union. 
the Huasco valley relies on the water resources from the upper catchments in high-altitude areas (Viviroli et al., 2007). The demand for water resources is growing as a consequence of developing agriculture and mining industry (Oyarzún and Oyarzún, 2011). Hence, concerns about the water supply are rising in the area. Glaciers are often perceived as important water reservoirs in the region, but no quantitative study allows such a statement. Favier et al. (2009) showed that, at the regional scale, the main water source is the seasonal snowpack. However, the authors pointed out the fact that glacier contribution needs to be further addressed, because few data were available in high-altitude catchments where glaciers exist.

In the studied catchments, data from a five year glaciological monitoring program and streamflow measurements are available, allowing us to address the question: how much meltwater originates from the glaciers in this area? To the authors knowledge such a base study has never been carried out in the whole Dry Andes of Chile. Corripio et al. (2007) called for this type of evaluation in the Dry Andes to anticipate the magnitude of changes in future water supply. Rivera et al. (2002) emphasized that until 2002 there was only one mass balance record in Chile (Echaurren Norte, Central Andes $33^{\circ} \mathrm{S}$ Escobar et al., 1995), which reflects the limitations of hydro-glaciological research elsewhere in the Dry Andes of Chile. The only hydro-glaciological studies in the Dry Andes are concentrated in the Central Andes $\left(31^{\circ} \mathrm{S}-35^{\circ} \mathrm{S}\right)$, where glacier cover is much larger $\left(2^{\prime} 200 \mathrm{~km}^{2}\right.$, Lliboutry, 1998). Pellicciotti et al. (2008) studied the summertime energy balance of the Juncal Norte glacier $\left(33^{\circ} \mathrm{S}\right)$ for a 2-month period in 2006. In this area, Pellicciotti et al. (2007) attributed a significant decreasing annual and seasonal trend of streamflow in the Aconcagua basin glaciers to a decrease in the contribution from glaciers and snowcover. However, Casassa et al. (2008) differed with this conclusion, observing at a larger scale, slightly, although not significant, positive mean monthly runoff trends in several basins between $28^{\circ} \mathrm{S}$ and $47^{\circ} \mathrm{S}$, suggesting an increase of glacier melt in the Andes.

In addition to the lack of data, hydro-glaciological studies in the Dry Andes must cope with the effect of snow and ice sublimation on the water balance. Low air humidity combined with high solar radiation and strong winds result in large sublimation rates. Sublimation contributes to the formation of snow and ice penitents that were described as distinctive features of the Dry Andes glaciers by Lliboutry (1998). Ginot et al. (2006) reported that sublimation amounts to $89 \%$ (327 $\mathrm{mm}$ w.e.) of the mean annual ablation near the summit of Cerro Tapado between 1962 and 1999 ( $5536 \mathrm{~m}$ a.s. $1,30^{\circ} 08 \mathrm{~S}, 69^{\circ} 55 \mathrm{~W}$ ). Nonetheless, similar, albeit less extreme conditions occur for example in the High Atlas Mountains of Morocco, where sublimation was estimated to amount to $44 \%$ (77 mm w.e.) of the seasonal snowpack ablation at $3000 \mathrm{~m}$ a.s.l. (Schulz and de Jong, 2004). The same authors noted the wide range of sublimation rates that were observed by other groups in arid mountains, emphasizing the fact that sublimation losses can considerably reduce runoff and groundwater recharge in already dry environments. Sublimation has been extensively studied in the Tropical Andes (Wagnon et al., 1999; Winkler et al., 2009), but the results are not necessarily applicable in the Dry Andes because the climatic conditions differ significantly (e.g. seasonal variability is less pronounced in the tropics).

In this study we specifically address the uncertainty associated with the sublimation in the calculation of the glacier contribution to streamflow. We combine glacier mass balance data and lysimeter data to calculate the mean annual glacier runoff in five automated water level gaging stations. Then, we compare the results with the mean annual discharge measured at these stations. The effect of El Niño is assessed from a qualitative analysis of the streamflow records. We also present direct measurements of meltwater discharge to gain insights into the instantaneous contributions of glaciers to streamflow in summertime and estimate their effective melting rates. The results are discussed in the light of the various peculiar processes that govern glacier and runoff dynamics in this area.

\section{Site description}

The study area is located in the Andes Cordillera of northerncentral Chile, near the Argentinean border, in the upper part of the Huasco drainage basin (Atacama Region). The elevation ranges between $2600 \mathrm{~m}$ and $5200 \mathrm{~m}$ a.s. 1 .

From a climatic perspective it belongs to the Desert Andes, i.e. the northern part of the Dry Andes (north of latitude $31^{\circ} \mathrm{S}$ ), according to the division of the Chilean and Argentinean Andes by Lliboutry (1998). In this semi-arid area, although elevation frequently exceeds $5000 \mathrm{~m}$ a.s.l., glacier cover is limited by low precipitation and high shortwave radiation rates due to low nebulosity (Nicholson et al., 2010). Precipitation from westerly circulation is concentrated in austral winter and occurs almost exclusively as snowfall. Episodic easterly rainfall events can occur in summertime (during the so-called Altiplano winter or Bolivian winter, between December to February), but they do not represent a significant amount of the annual precipitation. At the El Indio mine, located $45 \mathrm{~km}$ south of the study area at an altitude of $3869 \mathrm{~m}$ a.s.l, the annual average precipitation computed from a 24-year monthly record is $173 \mathrm{~mm}$ (Golder Associates S. A., 2009) and $81 \%$ of the precipitation occurs between May and August. The precipitation interannual variability is marked and partly controlled by the El Niño Southern Oscillation (Montecinos et al., 2000). The typical pattern that was already described by Lliboutry (1954) is a succession of dry years interrupted by a wet year every five years in average.

We focus on two headwaters of the Huasco basin, the Estrecho River and the Potrerillos River with its tributary Del Toro River (Fig. 1). Although these streams arise from 

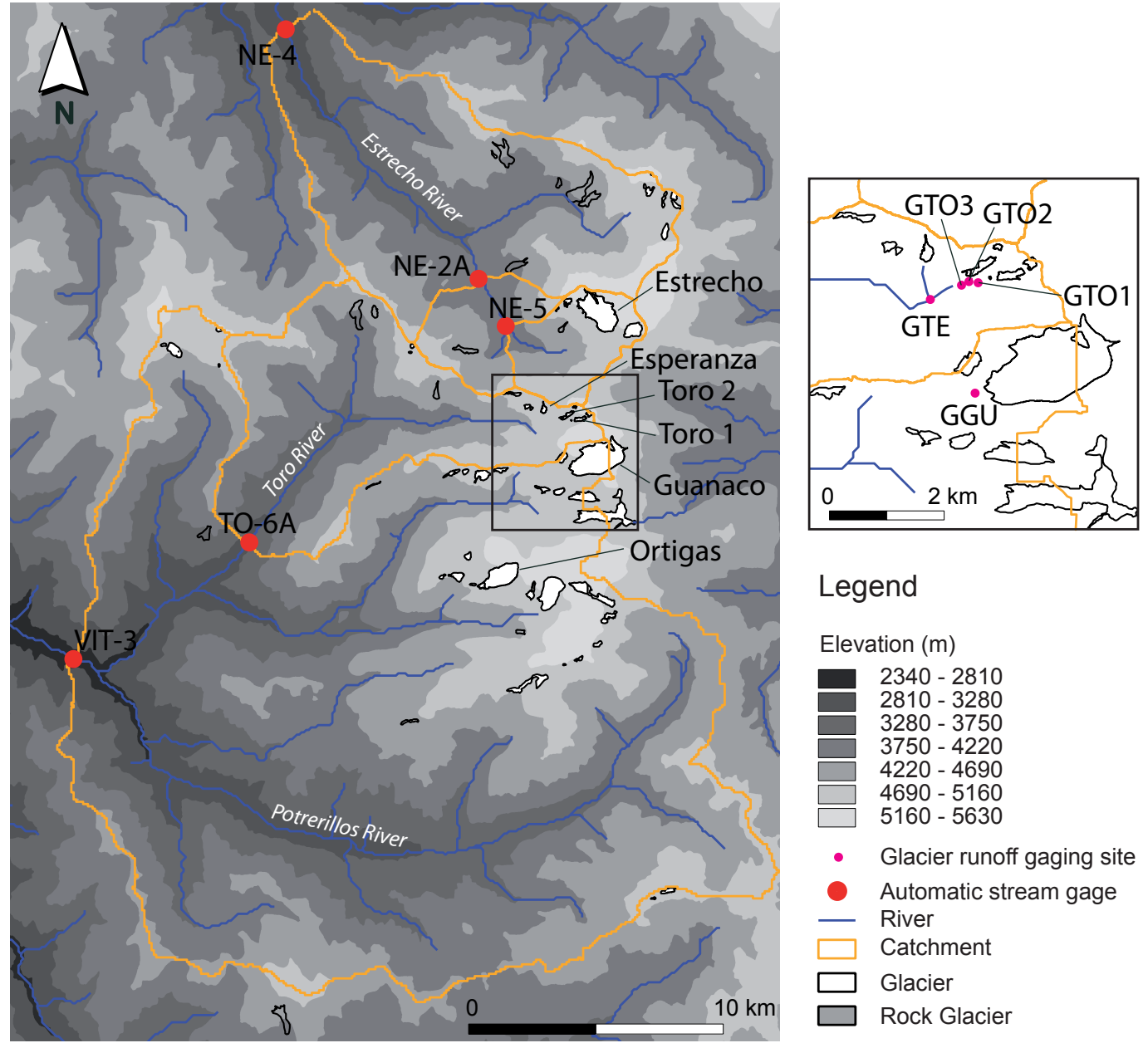

\section{Legend}

\begin{tabular}{|c|c|}
\hline Ele & tion (m) \\
\hline & $\begin{array}{l}2340-2810 \\
2810-3280 \\
3280-3750 \\
3750-4220 \\
4220-4690 \\
4690-5160 \\
5160-5630\end{array}$ \\
\hline & Glacier runoff gaging site \\
\hline & $\begin{array}{l}\text { Automatic stream gage } \\
\text { River } \\
\text { Catchment }\end{array}$ \\
\hline & Glacier \\
\hline & Rock Glacier \\
\hline
\end{tabular}

Fig. 1. Map of the study area.

two small neighboring catchments, they actually belong to two major subcatchments of the Huasco Basin. Estrecho River is a tributary of El Tránsito River (catchment area $4135 \mathrm{~km}^{2}$ ) and Potrerillos River is a tributary of El Carmen River (catchment area $2890 \mathrm{~km}^{2}$ ). The confluence of El Tránsito River and El Carmen River is located in Junta del Carmen (790 m a.s.1.), where the Huasco River begins, about $80 \mathrm{~km}$ north west from the study area (Dirección General de Aguas, 2004).

The studied catchments encompass various ice bodies, including glaciers, glacierets, debris-covered glaciers and rock glaciers (Nicholson et al., 2010). In this paper we consider only apparent ice bodies, i.e. glaciers and glacierets. Unlike a glacier, a glacieret is a small ice body with little or no sign of flow. For the sake of simplicity we use the word glacier to designate both landforms in the following sections. All studied glaciers can be classified as cold glaciers (Rabatel et al., 2011).
The surface geology is dominated by large outcrops of granitic bedrock. Valley floors are filled with Holocene sediments, including glacial till, alluvial and colluvial deposits. The studied streams drain the Chilean side of the PascuaLama mine protocol area. Pascua-Lama is an open-pit gold and silver mine project. The initial excavation project implied the transport of glacial ice and caused a controversy, demonstrators raising concern over the impact of the mine on water supply in the lowlands (Fields, 2006). The pit limits were revised as to avoid interference with the glaciers and the project received the final permit from Chilean government on 22 September 2009. The exploiter (Compañia Minera Nevada, CMN) has committed to monitoring various potential environmental impacts of the mining activity, including glaciers and streamflow changes. CEAZA was mandated to implement the glacier monitoring plan approved as part of the environmental impact assessment process for the Pascua-Lama project (Comisión Regional del Medio Ambiente, 2006), while other aspects of the cryospheric and 
Table 1. Automatic stream gage stations characteristics (2003/2004-2007/2008).

\begin{tabular}{llllrrr}
\hline Name & $\begin{array}{l}\text { Elevation } \\
(\mathrm{m} \text { a.s.l. })\end{array}$ & River name & Sub-basin & $\begin{array}{r}\text { Catchment area } \\
\left(\mathrm{km}^{2}\right)\end{array}$ & $\begin{array}{r}\text { Glacier cover } \\
(\%)\end{array}$ & $\begin{array}{r}\text { Rock glacier cover } \\
(\%)\end{array}$ \\
\hline NE-5 & 3978 & Estrecho & Tránsito & 15.3 & 10.80 & 0.2 \\
NE-2A & 3850 & Estrecho & Tránsito & 29.6 & 5.56 & 0.5 \\
NE-4 & 2969 & Estrecho & Tránsito & 128.6 & 1.55 & 0.9 \\
TO-6A & 3160 & Toro & Carmen & 75.4 & 0.39 & 0.4 \\
VIT-3 & 2620 & Potrerillos & Carmen & 507.5 & 1.12 & 0.1 \\
\hline
\end{tabular}

hydrological monitoring is shared between various private consulting companies. This context explains the exceptional wealth of hydro-glaciological data in this remote area.

\section{Data}

\subsection{Topography}

We used two Digital Elevation Models (DEM):

- a 2-m horizontal resolution DEM generated from a 2005 Ikonos stereo pair, with a vertical absolute height error estimated as less than $5 \mathrm{~m}$;

- a 90-m horizontal resolution DEM extracted from the Shuttle Radar Topography Mission (SRTM) global product, with a vertical absolute height error of less than $16 \mathrm{~m}$ (Farr et al., 2007).

As the Ikonos DEM covers only a fraction of the studied area (38\% of the total catchments area), we used the SRTM DEM to obtain a complete DEM of the studied area.

\subsection{Hydrology}

We used hourly discharge measurements recorded since 2002 at five automatic stream gages stations distributed between $2620 \mathrm{~m}$ a.s.l. and $3978 \mathrm{~m}$ a.s.l. (Table 1). In these stations the discharge is measured using a Parshall flume equipped with an automatic water level recorder. This dataset was completed by several manual discharge measurements conducted in summer at the snouts of four glaciers by CMN staff using a current meter. These measurements were assumed to be a direct measure of the glacier meltwater discharge.

Using the automatic discharge measurements, the mean monthly discharge $(Q)$ and relative variation of the mean monthly discharge $(A=(\max Q-\min Q) / \min Q)$ were computed (Fig. 2). Discharge variations indicate that the hydrological regime is dominated by snow and glacier melt, as minimal annual discharge occurs in winter (i.e. the wet season) while the annual flood occurs in summer (January or February). The influence of glacier melt is the strongest at NE-5, as the relative variation of discharge is the largest. The summer flood is concentrated during January and March
(58\% of the mean annual discharge), while discharge remains low between April and December.

In the Estrecho River, the relative variation of the mean monthly discharge decreases rapidly from NE-5 to NE-4. The maximum discharge occurs in January at NE-4 and NE-2A, while it occurs later at NE-5, in February. All these observations suggest a decreasing influence of glacier melt along the Estrecho River from NE-5 (3978 m) to NE-4 (2969 m), in favor of snowmelt. In the Potrerillos catchment, in contrast, the annual flood occurs earlier in the Toro River at TO-6A $(3160 \mathrm{~m})$ than in the downstream Potrerillos River at VIT-3 $(2620 \mathrm{~m})$, indicating a lower influence of glacier melt at TO6-A than at VIT-3. Relative discharge variations at TO$6 \mathrm{~A}$ and VIT- 3 are similar.

Both catchments are also characterized by a marked diurnal discharge variation (Fig. 2). This is a typical feature of catchments dominated by snow and glacier melt, which results from the control of temperature and solar radiation on melting. The amplitude of this cycle decreases from NE-5 to NE-4. Conversely, the diurnal variations are less marked at TO-6A than VIT-3, which is consistent with a lower influence of glacier melt. The attenuation and offset between the peak flows from NE-5 to NE-4 reveals the propagation of the daily glacier meltwater peakflow in the Estrecho river.

\subsection{Glaciology}

The recent glacier inventory of the Huasco valley by Nicholson et al. (2010) allowed us to identify 74 glaciers and glacierets in the studied catchments. Glacier areas were taken from the inventory, but when possible, the glaciers contours were refined using an orthorectified Ikonos image of the Pascua-Lama area (date of acquisition 26 March 2007). The temporal variations in glacier area was not accounted for in this study. Rabatel et al. (2011) estimated that the glacier area decreases by less than $2 \%$ per year in average $(1.07 \%$ over 1996-2005 and 1.75\% over 2005-2007), what we considered negligible for our period of study (5 years), as we are focusing on the average contribution.

We also used the accumulation, ablation and mass balance data collected for four to seven glaciers between 2003/2004 and 2008/2009 using a distributed stake network (Table 2). Accumulation data were collected once a year in late winter 

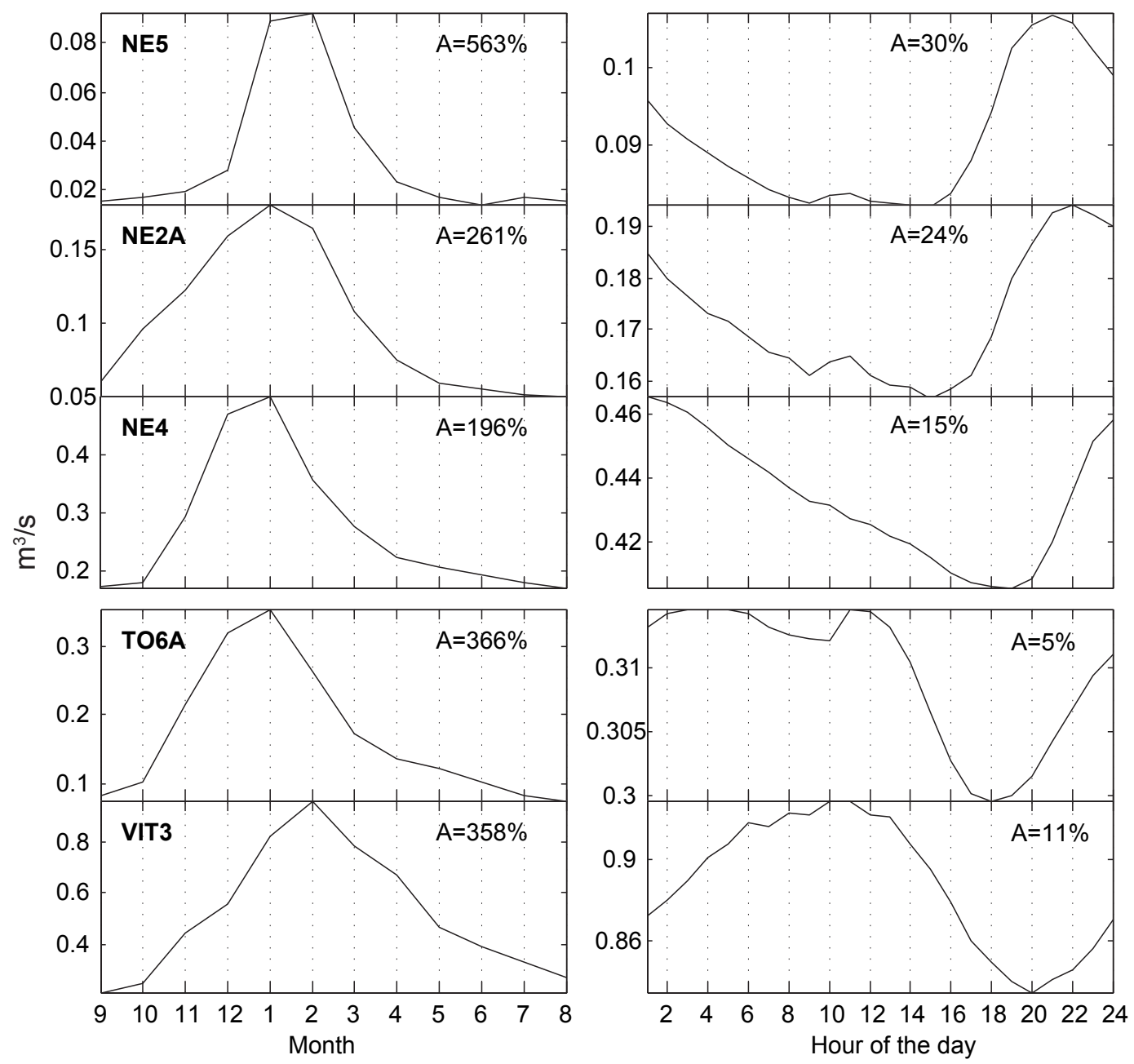

Fig. 2. Left: mean monthly discharge (2003/2004-2007/2008). Right: mean hourly discharge in January and February (2003/20042007/2008). $A$ is the relative variation of the maximum value with respect to the minimum value. NE-5, NE-2A and NE-4 stations are located in the Estrecho River catchment (upper panel), while TO-6A and VIT-3 stations are located in the Potrerillos River catchment (lower panel).

(late summer for ablation). Due to the small size of the studied glaciers, the stake network is relatively evenly distributed on the glacier. This dataset was completed with the mass balance values obtained for 2002/2003 by differencing ground penetrating radar profiles (Golder Associates S. A., 2009). All these data are described by Rabatel et al. (2011).

We finally gathered the results from twelve snow lysimeter experiments carried out between 2008 and 2010 (Table 3, Fig. 3). Lysimeters have been used for snow sublimation measurements by Winkler et al. (2009). Lysimeters were filled with snow or ice collected on the glaciers (Toro 1 and Guanaco) or in La Olla weather station located near NE-5 stream gage. Lysimeters were placed on the glaciers, except for La Olla site where they were placed on the snow cover. They were left several consecutive days to account for the effect of the diurnal cycle on the sublimation and melting rates.
Table 2. Instrumented glaciers in the study area (for which ablation, accumulation and net balance data are available). For the Guanaco glacier we indicated in parenthesis the area of the glacier which is within VIT-3 catchment (contributing area). For gage station characteristics refer to Table 1.

\begin{tabular}{lll}
\hline Name & Area $\left(10^{4} \mathrm{~m}^{2}\right)$ & Gage station \\
\hline Toro 1 & 7.80 & T0-6A, VIT-3 \\
Toro 2 & 6.61 & T0-6A, VIT-3 \\
Esperanza & 4.69 & T0-6A \\
Estrecho & 131 & NE-5, NE-2A, NE-4 \\
Guanaco & $184(126)$ & VIT-3 \\
Ortigas & 87.4 & VIT-3 \\
\hline
\end{tabular}




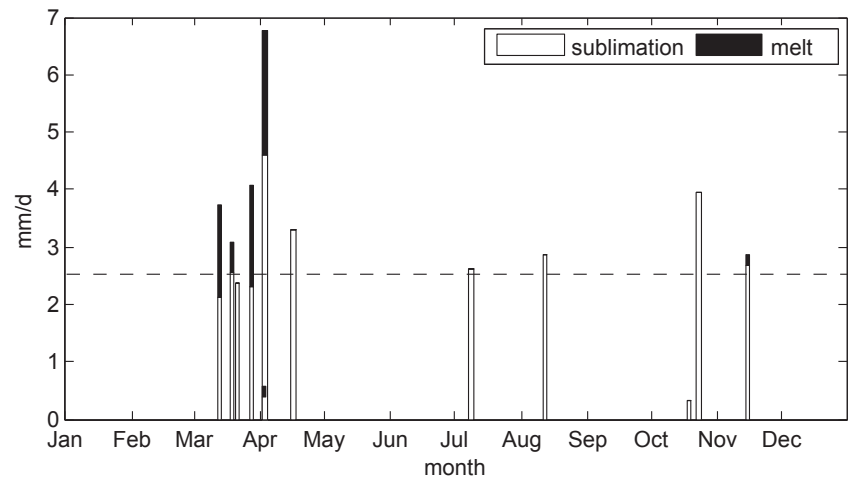

Fig. 3. Ablation, sublimation and melting rates from lysimeter experiments $\left(\mathrm{mm}\right.$ w.e. $\left.\mathrm{d}^{-1}\right)$. Dotted line: mean sublimation rate.

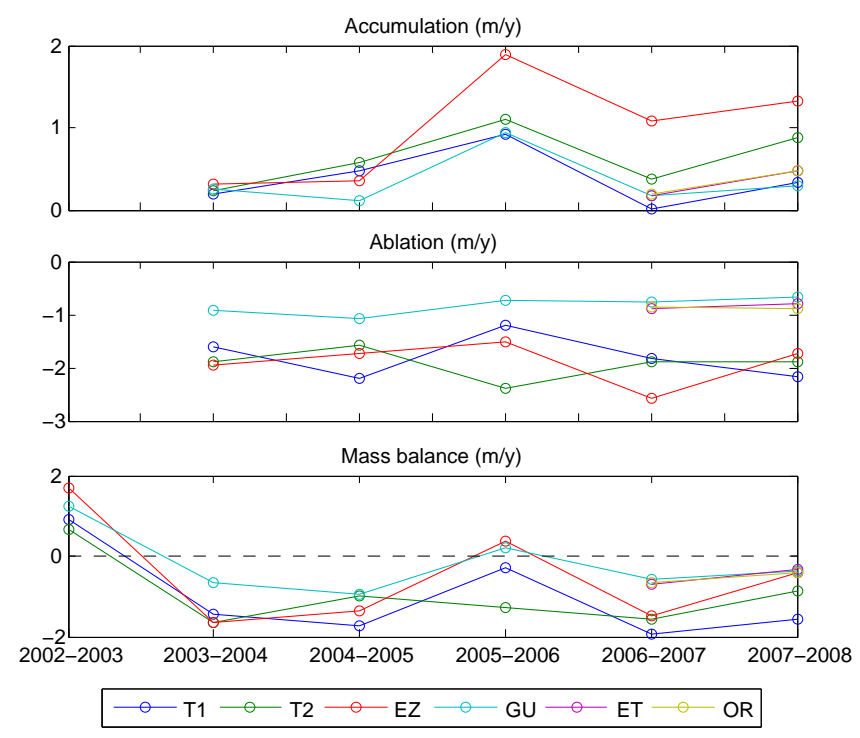

Fig. 4. Glacier mass balance data (mw.e. $\left.\mathrm{yr}^{-1}\right)$; $\mathrm{T} 1$ : Toro 1, $\mathrm{T} 2$ : Toro 2, EZ: Esperanza, GU: Guanaco, ET: Estrecho, OR: Ortigas.

Lysimeters are composed of a top plastic container with small holes drilled at its bottom, embedded onto a second, lower hermetic container used to collect meltwater percolating from the top container. The apparatus is inserted so that the top container is level with the snow surface. Surrounding snow was used for snow experiments while refrozen water was used for ice experiments. Melting is measured by weighting water accumulated in the bottom container, while sublimation is calculated from mass loss in the top container (total ablation) minus the melting amount. Experiments that experienced snowfall, or that had water refreezing inside the top container, were excluded.
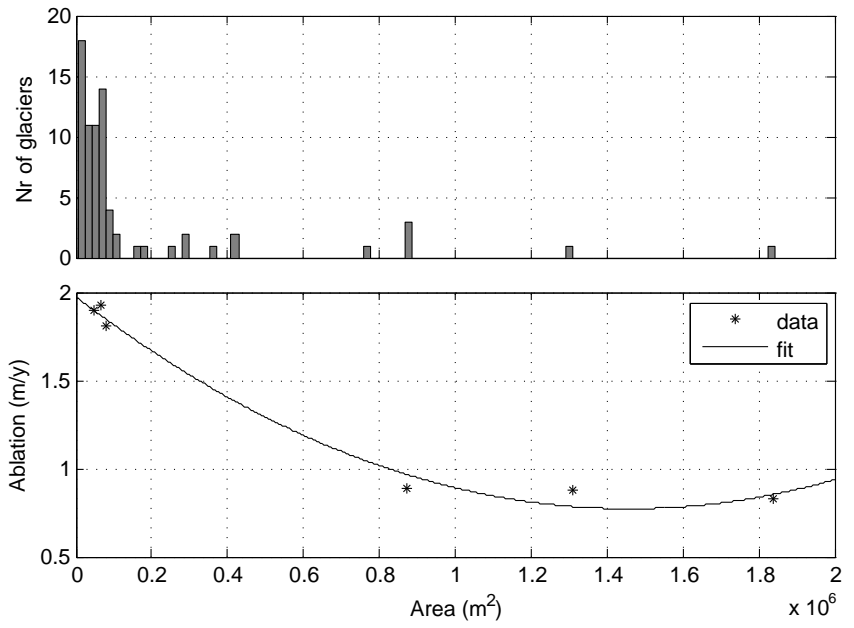

Fig. 5. (a) Glacier area distribution; (b) Ablation-area relationship $\left(\mathrm{m}\right.$ w.e. $\mathrm{yr}^{-1}$ ).

\section{Methods}

\subsection{Catchment delineation}

The five watersheds were delineated using the ArcGIS Desktop Hydrology toolset. For this purpose a depressionless DEM was created from the merged SRTM-Ikonos DEM.

\subsection{Annual contribution}

\subsubsection{Annual discharge}

The 2003/2004-2007/2008 period was divided in five hydrological years beginning in September, as it corresponds to the onset of the melt season and the lowest mean monthly flow. The annual discharge was computed after linear interpolation of the missing values. The interpolation was made using the daily mean values. The interpolated discharge values represent $15 \%$ of the whole dataset. This means that $15 \%$ of the data are missing for a period greater than one day, as we used daily mean values to interpolate. If one considers the original hourly dataset, then $17 \%$ of the values are missing. A more sophisticated approach based on a multiple regression analysis of the five discharge records was discarded because it led to equivalent results.

\subsubsection{Glacier melt}

The mean specific annual glacier melt $F$ (in meters per year) was computed as:

$F=\mathrm{Ab}-S$

where $\mathrm{Ab}$ and $S$ are the means of the specific annual ablation and sublimation rates over the period 2003/2004-2007/2008. 
The mean annual melt was divided by the mean annual discharge at the five automatic stations to obtain the relative contribution of glaciers to streamflow, under the assumption that meltwater flow is preserved from the glacier snout to the stream gage.

\subsubsection{Glacier ablation}

The annual ablation rates are directly available through stake measurements for the six monitored glaciers (Fig. 4). Monitoring on Ortigas and Estrecho glaciers only began in 2007. The missing ablation and accumulation values for these glaciers over the period 2003/2004-2005/2006 were set to the values measured on the Guanaco glacier. We considered that this was the best option because their tendencies were similar in 2006/2007 and 2007/2008 (Fig. 4).

The ablation rates of the other glaciers (non-monitored) were determined by a simple curve fitting exercise. Data from the monitored glaciers suggest that the ablation rate is inversely proportional to the glacier size (Fig. 5). This relationship was fitted using a quadratic polynomial function. The function was chosen empirically because the sample size is too small to assess the statistical performance of the fitting function. Ablation rates were extrapolated to the other glaciers based on the regression results. Figure 5 shows that the regression is mainly applied to glaciers with area less than $2 \mathrm{~km}^{2}$, because this subset contains most of the glaciers. We expect that they are relatively well constrained by the measurements made on the three monitored glacierets Toro 1, Toro 2, Esperanza. Rabatel et al. (2011) discussed the possible processes explaining the different abaltion rates found between small and large glaciers in this area (see also Sect. 6.3).

Glaciers in this area do not have distinct ablation and accumulation areas (Rabatel et al., 2011), i.e. the concept of equilibrium line altitude is not relevant in this context. This was illustrated in the case of the Guanaco glacier by Rabatel et al. (2011), where no ablation dependence with altitude is apparent for two contrasted years. Therefore, we considered in this study that ablation and accumulation are uniformly distributed over the whole glacier area.

The relative contribution of glacier mass loss (due to negative mass balance) to the ablation total was computed as:

$\alpha=\frac{\Delta M}{\mathrm{Ab}}$

where $\Delta M$ is the mean specific mass balance over the period 2003/2004-2007/2008. In Pascua-Lama, $\Delta M$ is negative for all instrumented glaciers, thus $\alpha>0$. Using the mass balance equation:

$\mathrm{Ac}+\mathrm{Ab}=\Delta M$,

we can write:

$\left\{\begin{aligned} \Delta M & =\alpha \mathrm{Ab} \\ \mathrm{Ac} & =(1-\alpha) \mathrm{Ab}\end{aligned}\right.$
The $\alpha$ ratio was further used to estimate the part of the glacier melt that is attributable to glacier mass loss $\left(F_{\Delta M}\right)$ and to seasonal snow accumulation $\left(F_{\mathrm{Ac}}\right)$ :

$$
\left\{\begin{aligned}
F_{\Delta M} & =\alpha F \\
F_{\mathrm{Ac}} & =(1-\alpha) F
\end{aligned}\right.
$$

\subsubsection{Glacier sublimation}

The annual sublimation was computed in two ways: (i) by averaging the absolute sublimation rates obtained from the lysimeter experiments (Table 3); (ii) by averaging the fraction of sublimation to total ablation from the same experiments and then applying the mean ratio to each glacier's ablation value (see previous section). The two methods were noted $\mathrm{S} 1$ and S2, respectively. The sublimation rates are $2.5 \mathrm{~mm} \mathrm{~d}^{-1}$ for $\mathrm{S} 1$ and $77 \%$ of the total ablation for S2 in 2003/2004-2007-2008. Thus we obtained two estimations of meltwater discharge that were averaged for graphic representation and analysis of the results. We used both estimations as lower and upper bounds for the error bars.

\subsection{El Niño effect}

The study area was affected in winter 2002 by an El Niño episode. The Oceanic Niño Index (ONI) was greater than one for six consecutive months (NOAA National Weather Service, Center for Climate Prediction, 2010). This caused heavy winter snowfalls in the study area. In the period of study, ONI > 1 also occurred in 2006 but it was in summer (dry season), and only for two months. The glacier contribution in 2002/2003 was analyzed separately as the lack of ablation data in 2002/2003 does not allow the previous methodology for computing the glacier contribution to be applied (Sect. 4.2.2). This separate analysis consisted in comparing monthly discharges of the hydrological years 2003/20042007/2008 with the monthly discharge of hydrological year 2002/2003 for each automatic stream gage station.

\subsection{Hourly contribution}

We used the manual discharge measurements made in summer near the glacier fronts in the VIT-3 catchment to evaluate the contribution of glacier meltwater to downstream flow at the hourly timescale (Table 4 ). The measurements were performed on 7 February 2006; 8 February 2006; 9 February 2006; 18 January 2007 and 8 February 2007. Data are scarce because discharge measurements were only feasible in summer when the upper reaches were not covered by snow.

We used these data to compute the maximal hourly contribution of glacier meltwater to VIT-3 hourly discharge on these days. For each day, the maximum measured discharge was divided by the discharge at VIT-3 after a delay corresponding to the travel time in the river network. The Esperanza glacier discharge (noted GE) was reconstructed by calculating the difference between GTE and GTO-3 when possible. 

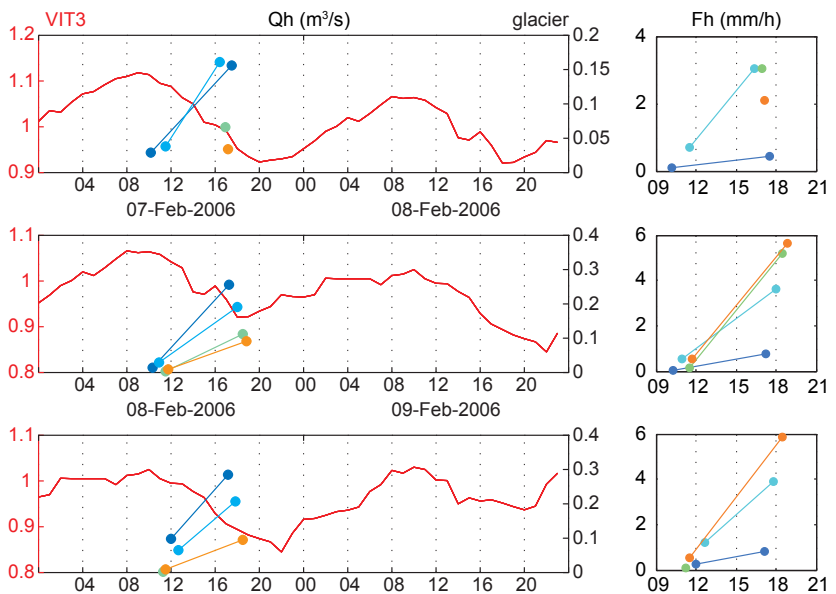

09-Feb-2006

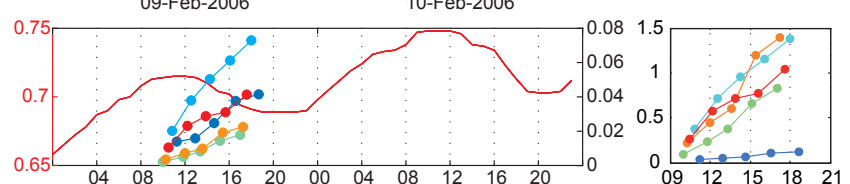
18-Jan-2007

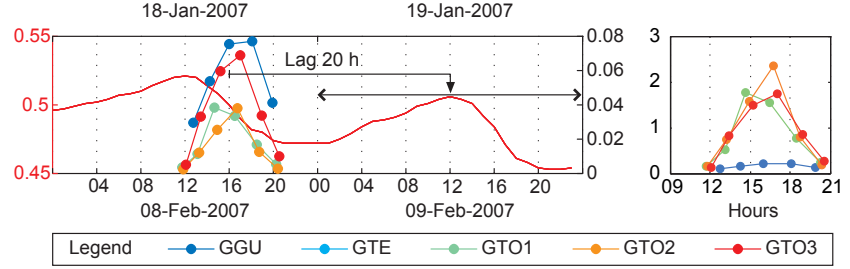

Fig. 6. Left: hourly discharge $\left(\mathrm{m}^{3} \mathrm{~s}^{-1}\right)$ at VIT3 automatic station (continuous red line) and instantaneous measurements of glacier runoff (see Table 4). Right: glacier discharges were converted to specific rates of melting $\left(\mathrm{mm}\right.$ w.e. $\left.\mathrm{h}^{-1}\right)$. Hours are given in local time.

The travel time between the measurement sites and VIT-3 automatic station was estimated based on an empirical analysis of the hydrographs (Fig. 6). First, we identified the date with a maximum of available measurements ( 8 February 2007). On this day a total of 23 discharge measurements were made at four points (GGU, GTO-1, GTO-2 and GTO3 ). These data allowed us to characterize the meltwater diurnal cycle and compare it to downstream flow at VIT-3 over the next hours (Fig. 6). The time lag between both peaks was estimated to be $20 \mathrm{~h}$. To account for the fact that this estimation was only done for one day, the hourly glacier contribution at VIT-3 was also calculated for a wide range of travel time: $20 \pm 12 \mathrm{~h}$ (see the bottom panel in Fig. 6). We assumed that the same range can be applied to GTO-1, GTO-2, GTO3, GGU, GTE and GE (Fig. 1), given the fact that the river lengths and the elevation difference between all these sites and VIT-3 are similar (Table 4).

This choice was further assessed using a simple flow velocity calculation. The Chézy formula was applied to the river section between GTO-3 (4753 m) and VIT-3 (2620 m) using a Manning's roughness coefficient ranging between

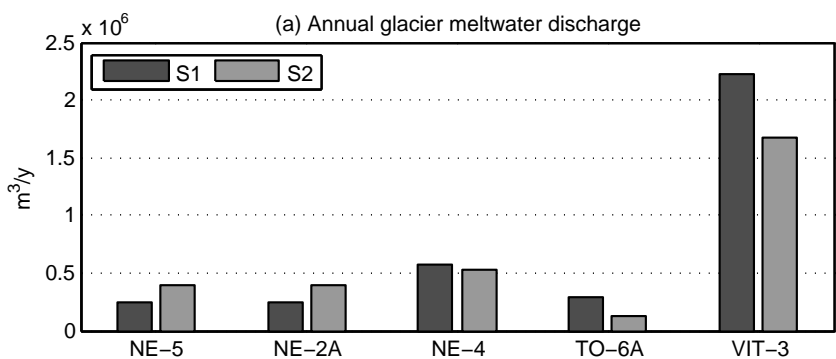

(b) Glacier area vs. glacier discharge
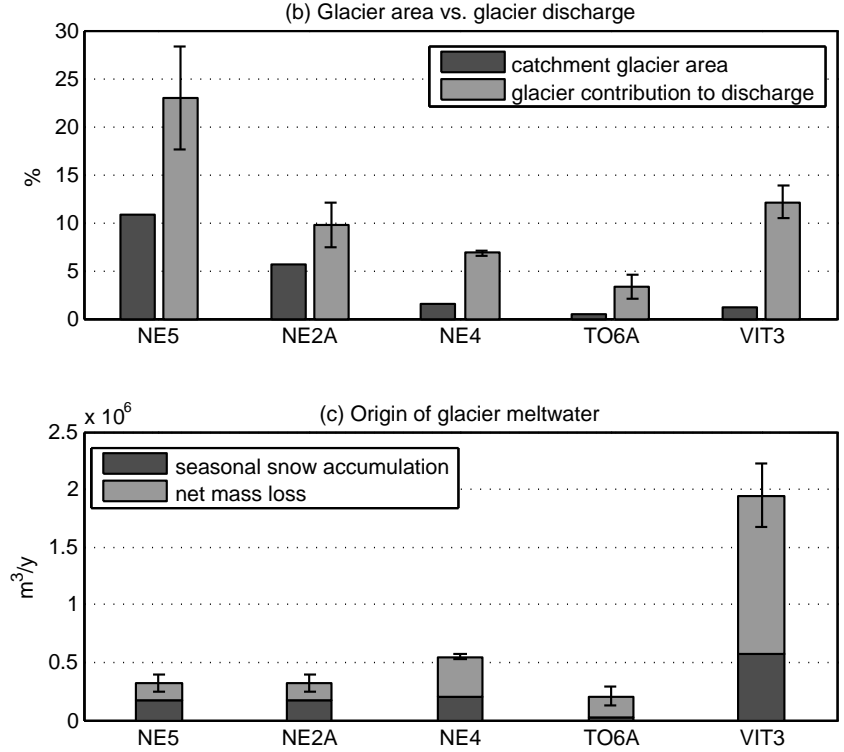

Fig. 7. Mean annual glacier contribution to streamflow per catchment over hydrological years 2003/2004-2007/2008. (a) Absolute contribution for each sublimation estimations, (b) relative contribution compared with catchment glaciated fraction, (c) contribution of annual accumulation and net mass loss to glacier melt. Each error bar is associated with the total glacier melt discharge.

0.05 and 0.09 (Chow, 1959). An approximate river length of $26 \mathrm{~km}$ was computed using ArcGIS flow length tool and the Ikonos DEM. The river section was approximated by a rectangle of dimension $2 \mathrm{~m} \times 0.1 \mathrm{~m}$. The resulting travel time between GTO- 3 and VIT- 3 ranges between 9 and $12 \mathrm{~h}$. This result must be regarded with caution as it derives from a very rough estimate of the channel geometry. However, it falls within the chosen range of $20 \pm 12 \mathrm{~h}$ and thus corroborates this choice.

The manual measurements were finally used in conjunction with glacier areas to estimate the instantaneous specific melting rates of the glaciers. Assuming that melt is null before 08:00 and after 22:00 (LT) (when solar radiation is null), the specific melting rates were interpolated over the day to obtain a rough estimation of the daily melting rates for each glacier. 
Table 3. Lysimeter experiments summary (water equivalent) giving the sublimation rate in mm w.e. $\mathrm{d}^{-1}$ and as a fraction of the ablation rate

\begin{tabular}{lrrrrlr}
\hline Location & Day start & Day end & Month & Year & mmw.e. $\mathrm{d}^{-1}$ & Ablation fraction \\
\hline Toro 1 & 17 & 20 & 3 & 2008 & -2.57 & 0.8 \\
Toro 1 & 1 & 4 & 4 & 2008 & -0.38 & 0.51 \\
Toro 1 & 17 & 20 & 10 & 2008 & -0.32 & 1 \\
Guanaco & 9 & 21 & 11 & 2008 & -2.69 & 0.93 \\
Guanaco & 14 & 19 & 4 & 2009 & -3.29 & 1 \\
La Olla & 8 & 9 & 7 & 2009 & -2.63 & 1 \\
La Olla & 11 & 13 & 8 & 2009 & -2.86 & 1 \\
Toro 1 & 21 & 25 & 10 & 2009 & -3.95 & 1 \\
Toro 1 & 12 & 14 & 3 & 2010 & -2.13 & 0.25 \\
Ortigas & 19 & 23 & 3 & 2010 & -2.38 & 1 \\
Guanaco & 26 & 30 & 3 & 2010 & -2.32 & 0.24 \\
Toro 1 & 1 & 5 & 4 & 2010 & -4.61 & 0.53 \\
\hline
\end{tabular}

Table 4. Manual discharge measurement stations.

\begin{tabular}{llcc}
\hline Name & Glacier & $\begin{array}{c}\text { Altitude } \\
\text { (m a.s.1.) }\end{array}$ & $\begin{array}{c}\text { Approximate river } \\
\text { length to VIT-3 (km) }\end{array}$ \\
\hline GTO1 & Toro 1 & 4970 & 24.9 \\
GTO2 & Toro 2 & 4969 & 25.0 \\
GTO3 & Toro 1, Toro 2 & 4955 & 25.0 \\
GTE & Toro 1, Toro 2, Esperanza & 4726 & 24.1 \\
GGU & Guanaco & 4753 & 25.9 \\
\hline
\end{tabular}

Table 5. Estimated daily glacier melting rates (mm w.e. per day).

\begin{tabular}{lrrrrr}
\hline & 7 Feb 2006 & 8 Feb 2006 & 9 Feb 2006 & 18 Jan 2007 & 8 Feb 2007 \\
\hline GGU & 3.0 & 4.4 & 5.3 & 0.8 & 1.6 \\
GTE & 18 & 22 & 23 & 9.6 & \\
GTO-1 & & 28 & & 5.2 & 8.9 \\
GTO-2 & & 32 & 34 & 8.9 & 10 \\
GTO-3 & & & & 7.5 & 9.4 \\
\hline
\end{tabular}

\section{Results}

\subsection{Annual contribution}

Figure 7a shows the annual glacier meltwater discharges calculated at every station using the two sublimation methods $\mathrm{S} 1$ and S2. As expected, the sublimation term importantly modifies the results. The differences between the calculated meltwater discharges can be significant in terms of absolute value (e.g. at VIT-3 the difference is $560 \times 10^{3} \mathrm{~m}^{3} \mathrm{yr}^{-1}$ ), and relative to the annual streamflow (e.g. at NE-5 the difference represents $10 \%$ of the annual streamflow).

Despite these uncertainties, the results clearly show that glaciers and glacierets contribute to a large fraction of the runoff in these high-altitude catchments (Fig. 7b). Glacier contribution decreases along the Estrecho River from $23 \%( \pm 5 \%)$ at NE-5 station to $7 \%( \pm 0.2 \%)$ at NE-4 station (mean value for $\mathrm{S} 1$ and $\mathrm{S} 2$ ), as the relative glaciated area decreases as well (Fig. 7b). However, the decreasing influence of glacier melt with altitude is not a general rule. In the neighbouring Potrerillos catchment, whereas VIT-3 station is located downstream of TO-6A station, the glacier input is higher. The computed glacier contribution at VIT-3 ranges between $10 \%$ and $14 \%$ depending on sublimation, whereas it does not exceed $5 \%$ at TO-6A. This is due to the fact that the VIT-3 catchment encompasses Las Ortigas River which drains some large ice bodies, including Guanaco and Ortigas glaciers. These results are consistent with the previous description of the streamflow dataset (Sect. 3.2).

In Fig. $7 \mathrm{~b}$ the estimated meltwater fraction in total discharge is compared with the glaciated fraction for each catchment. This reveals a second result, that is the hydrological importance of glaciers within these catchments is much larger than their area. In other words, it indicates that glaciers generate more water per surface unit than the non-glaciated area of the catchment. This point is discussed in more details in Sect. 6.

The third result is the relative contribution of seasonal snow accumulation ( $F_{\mathrm{Ac}}$, Sect. 4.2.2) and glacier mass loss $\left(F_{\Delta M}\right)$ to the computed melt (Fig. $7 \mathrm{c}$ ). According to our calculation, the part of the glacier discharge that is attributable to glacier mass loss is substantial in all catchments and larger than the melt of accumulated snow in three catchments (NE4 , TO-6A, VIT-3) in average over the period of study.

\subsection{El Niño effect}

Figure 8 shows that El Niño conditions in 2002 modified both the volume and timing of discharge. The monthly discharges were higher than the 2003/2004-2007/2008 averages at all stations. The hydrological regime was also affected, with streamflow rising earlier in the spring. The hydrological regime at NE-5 was bimodal: an early annual flood occurred in November and was followed by a second 


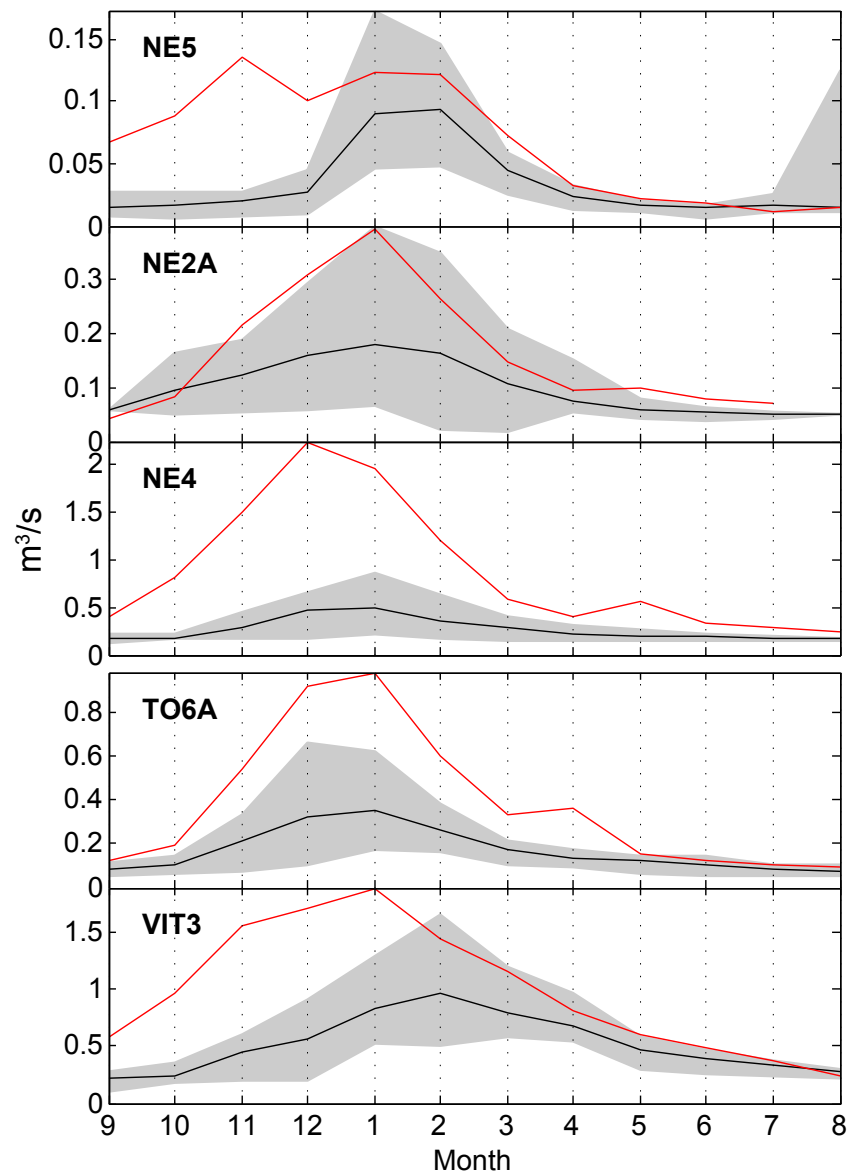

Fig. 8. Impact of El Niño on the hydrological regime. Black line: mean monthly discharge (2003/2004-2007/2008). Shaded: range of monthly discharges over the same period. Red line: monthly discharge in 2002/2003 (El Niño year). Note: NE-5 monthly discharge range is affected by a summertime rainfall event which occurred in August 2008 (example of an Altiplano winter event, see Sect. 2).

maximum in January. Comparison with the 2003/20042007/2008 series indicates that this early flood is due to an unusual snowmelt contribution. As a result, the glacier contribution in 2002/2003 was relatively much lower.

\subsection{Hourly contribution}

The few available glacier runoff measurements show the large diurnal variations in meltwater production during January and February (Fig. 6). The discharge was generally null or lower than $0.01 \mathrm{~m}^{3} \mathrm{~s}^{-1}$ before 12:00 and rose rapidly in the afternoon. Most of the measurements ended before the discharge decreased in the evening, except for the data collected on the 8 February 2007, which show that the peak discharge was reached between 16:00 and 18:00. This suggests that the maximum values recorded on the other days were close to the daily peak. Therefore, the calculated contribu-

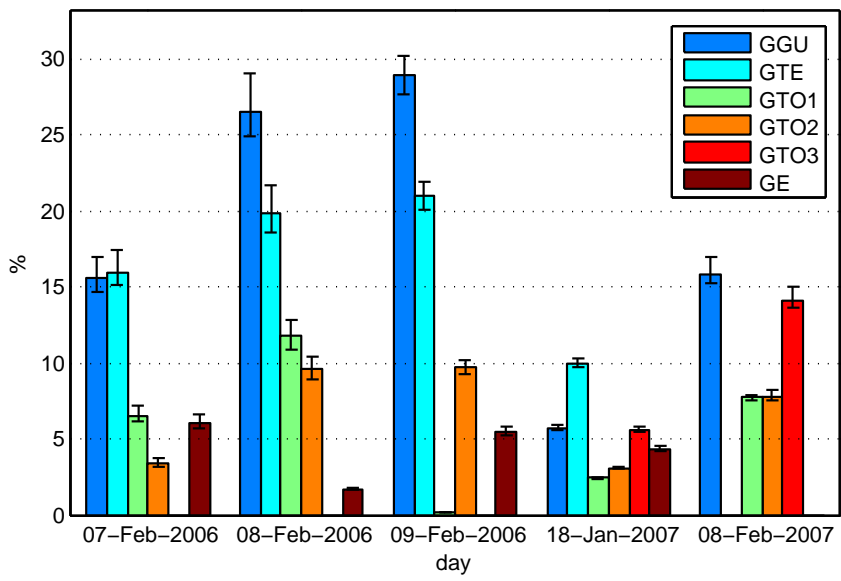

Fig. 9. Maximum hourly contribution of glacier meltwater to VIT3 discharge (error bars account for the uncertainty on discharge travel time).

tions to Potrerillos River should be close to the maximal values (Fig. 9).

Figure 9 illustrates the fact that glacier contribution to streamflow is substantial in summertime. Runoff measurements performed in 2006 suggest that glacier contribution to streamflow was higher in this year. For Guanaco the average of the maximum discharges is $0.2 \mathrm{~m}^{3} \mathrm{~s}^{-1}$ in 2006 and $0.05 \mathrm{~m}^{3} \mathrm{~s}^{-1}$ in 2007.

The VIT-3 discharge was also higher in 2006 than 2007, but the change was less pronounced than the change in the glacier discharges, which explains why the relative glacier contributions were higher in 2006 (Fig. 9). Maximum hourly contribution from Guanaco glacier exceeded $25 \%$ of VIT3 discharge on 8 February 2006 and 9 February 2006. In the VIT-3 catchment, Guanaco glacier represents $22 \%$ of the total glacier area $\left(5.70 \mathrm{~km}^{2}\right)$. The group of glaciers Toro 1 , Toro 2 and Esperanza (GTE station) contributed up to 20\%, whereas they represent only $3.4 \%$ of the catchment glacier area. The specific melting rates represented in Fig. 6 confirm that melting is significantly higher for this group of glacier in comparison with Guanaco glacier. The specific melting rates for GTE, GTO-1, GTO-2 and GTO-3 are remarkably consistent and always higher than Guanaco melting rate. The maximum melting rate was $6 \mathrm{~mm} / \mathrm{h}$ for the Toro 1 and Toro 2 glaciers in the late afternoon of the 8 February 2006 and 9 February 2006, while the maximal melting rate of Guanaco glacier on the same days probably did not exceed $1 \mathrm{~mm} / \mathrm{h}$.

Table 5 show the daily melting rates estimated from the hourly measurements (see Sect. 4.4) For the measurements days the estimated daily melting rates of Guanaco glacier varied between $0.8 \mathrm{~mm} \mathrm{~d}^{-1}$ and $5.3 \mathrm{~mm} \mathrm{~d}^{-1}$, while it varied between $5.2 \mathrm{~mm} \mathrm{~d}^{-1}$ and $34 \mathrm{~mm} \mathrm{~d}^{-1}$ for the Toro 1 , Toro 2 and Esperanza glaciers. 


\section{Discussion}

\subsection{Annual contribution}

In Sect. 5.1 we calculated the mean annual contribution of glaciers to downstream river discharge over 2003/20042007/2008 using mass balance data. The contribution varies among the catchments between $3 \%$ to $23 \%$. These estimations are based on the hypothesis that the meltwater volume is conserved from the glaciers to the stream gage stations. In other words, we assumed that the evaporation loss is negligible within the catchment. We think this hypothesis is reasonable in such high-altitude hydroclimatic context where topographic gradients are large and vegetation cover is very sparse. The only vegetation patches are the bofedales (highaltitude Andean wetlands). Preliminary analysis of evapotranspiration measurements conducted on the main bofedal of the study area indicated that annual evapotranspiration from the bofedales is low because the climate is cold and arid throughout most of the year. Apart from the bofedal areas, the bare soil evaporation was presumed negligible because there is no soil layer to store water.

The main uncertainty stems from the sublimation. We partly accounted for this uncertainty by using two different calculation methods. However, both methods are based on annual averages (absolute rate or relative to ablation) deduced from the lysimeters and thus might be biased by the irregular distribution of the experiments over time (Fig. 3). The data variability does not allow the characterization of an annual cycle, which would be useful to improve the calculation of the mean annual flux. We have no evidence so far that the seasonal variations in sublimation rates are significant over the year, as it was observed in the tropical Andes of Bolivia and Peru (Wagnon et al., 1999; Winkler et al., 2009).

In spite of these uncertainties, it is evident that the annual contribution of glaciers is higher than their contributive area, as we emphasized in Sect. 5.1. According to our results, the runoff production per surface unit in the non-glacier areas is much lower than in the glacier areas. Such "glacier effect" in the catchment water balance can be explained by two main processes:

- Transport of snow onto glaciers by wind (snowdrift): by depleting the seasonal snowpack, snowdrift increases the snow accumulation on the glaciers. In the Dry Andes, snowdrift is known as an important process: for example, Ginot et al. (2006) invoked snowdrift to explain the presence of the Tapado glacier, despite the fact that higher peaks in the surroundings are glacier-free.

- Glacier mass loss: glacier mass balance has been largely negative during the period of study. Figure $7 \mathrm{c}$ shows that the glacier net loss contributes at least to half of the glacier runoff. Hence it can be concluded that the studied hydrological system is not in equilibrium with climate. We argue that this transient state results from the combination of two main effects: (i) a long term tendency due to global climate change (see Rabatel et al., 2011), (ii) a short term tendency driven by regional climatic oscillations (see below, Sect. 6.2).

\subsection{El Niño effect}

The estimation of annual contributions was restricted to the period 2003/2004-2007/2008. Because of the lack of ablation data we did not include the hydrological year 2002/2003, which was characterized by a strong positive mass balance (Fig. 4). In 2002, the climatic conditions were influenced by a positive phase of the El Niño Southern Oscillation, resulting in heavy snowfalls in the study area. Hence, the seasonal water balance in the hydrological year 2002/2003 was very different from the 2003/2004-2007/2008 average and one should be aware that our results might be biased by this restriction. The qualitative assessment of the streamflow records indicates that the seasonal snowpack contribution to streamflow was probably much higher, which consequently reduced the relative influence of glaciers on the local hydrology. The data show that the 2002 El Niño episode allowed a recharge of the glaciers, which was followed by five years of negative mass balance. Hence it partly explains why the fraction of net mass loss is so high during the period of study (Fig. 7c).

As we noted in Sect. 2 this pattern was already observed in the Nevado Juncal massif (Central Andes, $70^{\circ} \mathrm{W}, 33^{\circ} \mathrm{S}$ ) by Lliboutry (1954), who suggested that snow accumulates on the glaciers during wet years, while melting predominates during the following years. He also observed that the socalled "wet years" occur about every five years, without referring to El Niño. Therefore we think that it is critical to isolate this short term oscillation from the long term tendency due to climate change in order to assess the future water resource in northern-central Chile. Hence a more detailed analysis of the impact of El Niño on the inter- and intra-annual hydrological balance of these catchments is needed.

\subsection{Hourly contribution}

The inter-annual assessment was completed by the analysis of intra-day contributions at VIT-3 station in summer, when glacier contribution is maximum. Under the same water volume conservation hypothesis, it led to the conclusion that the contribution of the glaciers Toro 1, Toro 2 and Esperanza to the VIT-3 hourly discharge varied between $0 \%$ and $22 \%$ over the day in February 2006. We did not account for the flow attenuation in the stream network, which may reduce the actual maximum contribution by smoothing the late afternoon discharge peak. Hence, these estimations must be seen as maximal upper bounds. The result is still remarkable as this group of glaciers represents only $3.4 \%$ of the total glacier area in the VIT-3 catchment. In contrast, Guanaco glacier represents $22 \%$ of the total glacier area and its 
maximum contribution did not exceed $30 \%$. The conversion of the measured discharges into specific melting rates confirmed the difference of melting rates between Guanaco and the glacierets. The maximum daily rate of melting that can be estimated for Toro 2 is $34 \mathrm{~mm} \mathrm{~d}^{-1}$, whereas maximum daily rate of melting on Guanaco glacier is $5.3 \mathrm{~mm} \mathrm{~d}^{-1}$.

This discrepancy may be due to several factors:

- The observed annual ablation of small glaciers (or "glacierets" Toro 1, Toro 2 and Esperanza) is larger than the ablation of larger glaciers (Guanaco, Estrecho and Ortigas) (see Fig. 4, and Rabatel et al., 2011). In the Pascua-Lama area, the larger ablation rates affecting smaller glaciers may originate from two factors: (i) transfer of sensible heat and longwave emission from the surrounding terrain to the glacier (Francou et al., 2003); (ii) a lower albedo, and hence larger net solar radiation input, due to dust influx from the surrounding terrain. Smaller glaciers will have a greater part of their total area affected by these "border effects", which results in greater ablation rates.

- The sublimation/melting ratio might also be lower in Toro 1, Toro 2 and Esperanza, because of debris observed on their surfaces. Debris on a glacier reduces its albedo, which enhances melting (up to a certain threshold, see Singh and Singh, 2001). Therefore, even for a same ablation rate, debris-covered glaciers would tend to have larger melting rates.

- So far we considered that the whole glacier surface effectively contributes to ablation and melting (3.3). This hypothesis might be inexact for the Guanaco glacier. Indeed, penitent distribution is not uniform on the Guanaco glacier, unlike Toro and Esperanza glaciers. Penitents occur mainly in the lower part and edges of the glaciers, which may reflect a non-uniform distribution of ablation, and sublimation/melting ratio. As a consequence it is possible that the Guanaco contributing area to melting is smaller than its total area.

- A last possible cause implies the refreezing of meltwater in these cold glaciers. Refreezing causes internal storage of melted ice and snow and thus reduces the release of meltwater. Refreezing might be more pronounced in a larger glacier such as the Guanaco glacier, because vertical water channels are deeper and also because it takes longer for the meltwater to leave the glacier. For a same melting rate, the effective meltwater generation might be smaller for a larger glacier.

The large variations in discharge over the day in the upper reaches of the studied catchments reflect the diurnal cycle of energy balance at the surface of the glaciers. The diurnal cycle is much less marked at VIT-3, because it receives the contributions of several glaciers. These contributions are spread over the day owing to the spatial distribution of glaciers within the catchment (Fig. 1). Moreover, it is likely that part of the glacier meltwater circulates in the shallow alluvial aquifers located in the valleys floors, which may buffer the meltwater inputs from the catchment upper areas.

Finally, the observed melting rate can be compared with the results of Pellicciotti et al. (2008). Using an energy balance model, the authors computed a daily summertime melting rate in the ablation area of the Juncal Norte glacier $\left(33^{\circ} \mathrm{S}\right.$, Central Andes of Chile) ranging between $224 \mathrm{~W} \mathrm{~m}^{-2}$ and $259 \mathrm{~W} \mathrm{~m}^{-2}$, i.e. $57 \mathrm{~mm} \mathrm{~d}^{-1}$ to $67 \mathrm{~mm} \mathrm{~d}^{-1}$. The melting rates are higher in the Central Andes because the glacier ablation area occurs at lower elevations. In this lower part of the glacier, the mean summertime air temperature is higher, which implies that available energy is more easily used for melting. The authors mentioned that sublimation contributed to only $1 \%$ of the total modeled ablation.

\subsection{Other hydrological contributors}

The remaining part of the annual streamflow can be attributed to several sources, including seasonal snowpack melt, groundwater flow, rock glaciers and permafrost thaw.

- Seasonal snowpack: glacier contribution is large in the studied catchments, however, this contribution decreases at larger scale, while the snow melt contribution increases. As a result, melting of the seasonal snowpack is the major component of the water balance at the regional scale, as shown by Favier et al. (2009).

- A few rock glaciers occur in the study area (Fig. 1). There is growing evidence that rock glaciers could play an important role in the Dry Andes hydrology (Azócar and Brenning, 2010). However, there is no pilot study concerning the contribution of rock glaciers to streamflow in the Dry Andes, which could help to assess this component in Pascua-Lama.

- Permafrost was observed in the upper part of the studied catchments. Permafrost dynamics influence several hydrological processes such as groundwater recharge and runoff generation (Kuchment et al., 2000). Permafrost thaw may also contribute to summertime discharge.

- Groundwater: we mentioned groundwater flow as a possible explanation of the diurnal cycle attenuation across the VIT-3 catchment. Aquifer storage capacity in this highly uneven terrain is mainly limited by the extent of the aquifers in the narrow valleys. Nevertheless, the role of groundwater should be explored, as recent studies suggest that understanding the effect of groundwater dynamics on hydrological balance is critical to predict streamflow response to climate change in mountain areas (Tague et al., 2008). 
The present study does not provide direct evidence of the relative contribution of each of these components. More work is needed to progress in that direction, but some field data are already available (Golder Associates S. A., 2009).

\section{Summary and conclusion}

The lack of reliable and continuous streamflow data is a recurrent issue in mountain hydrology. Hence, the stream gage network density in the studied area is rather exceptional (five automatic stations in a total catchment area of $616 \mathrm{~km}^{2}$ ). Furthermore, the river discharge dataset can be combined with glacier mass balance measurements to investigate the hydrological importance of glaciers. This work enabled us to understand the effect of snow spatial redistribution and glacier mass loss upon the hydrological balance of this high-altitude, semi-arid area. We also used several manual discharge measurements made at the glacier snouts to compute the direct contribution of glacial runoff to downstream flow and the magnitude of the melt cycle.

We argue that a large part of the uncertainties on these results could be reduced in the future if a better knowledge of the glacier sublimation flux is achieved. Therefore, to go beyond the results of this paper, we plan to apply an energy balance model to the glaciers. First, a model will enable better characterization of the seasonal distribution of glacier melt, which is particularly relevant in terms of water resources. Moreover, a model would allow a better representation of the sublimation cycle and therefore a more accurate estimation of glacier runoff. The daily glacier melting rates estimated in this study (Table 5) will be valuable data for the calibration and validation of such a model.

The observed positive trend in temperature in the Andes of central and northern Chile $\left(+0.25^{\circ}\right.$ per decade, Falvey and Garreaud, 2009) is likely to persist in the next decades, as demonstrated by recent analyses of climate model simulations (Souvignet et al., 2010; Fiebig-Wittmaack et al., 2010). Such warming rate will affect the regional cryosphere and thus raises concern about the future of water resources. The results of this study can be used to speculate about the effect of projected glacier disappearance on river discharge in the Chilean side of the Pascua-Lama area, assuming that all other factors remain equal to their present value (i.e. no change in precipitation, nor in sublimation rates, seasonal snow cover, groundwater, etc.). At the annual timescale, if all glaciers would have disappeared, the mean discharge would be lower than the 2003/2004-2007/2008 mean, because glacier wasting (net mass loss) during this period has provided additional water to the annual hydrological budget. However it is important to recall that annual mass losses are partly compensated during wet years (e.g. El Niño) and thus it may be too simplistic to take the term $F_{\Delta M}$ (meltwater discharge from net mass loss, cf. Sect. 4.2.2) as an indicator of potential discharge loss. Longer glaciological and hydrological time series are required to address this issue.

A more robust projection can be made for summer streamflow, based on hourly discharge analysis. If Toro 1 , Toro 2, Esperanza and Guanaco glaciers were absent, the calculated discharge fractions shown in Fig. 9 would be zero. Therefore, glacier disappearance would significantly modify the hydrological regime of these high-altitude streams. It is not clear, however, to what extent this would affect the lower reaches of the Huasco Basin, which are dominated by snowmelt (Favier et al., 2009).

Acknowledgements. We acknowledge Compañia Minera Nevada for logistical and financial support and for sharing hydrological data. This work would not have been possible without the field data collected by the other members of the CEAZA glaciology unit: Roberto Garrido, José Luis Castro, José Araos, Jorge Marín, Hélène Castebrunet, Vincent Favier and Lindsey Nicholson. We also thank Gino Casassa and two anonymous reviewers for careful reading of the paper and insightful comments. This work was part of a research project funded by the Chilean national research agency (Fondecyt Iniciación en Investigación grant No. 11090445).

Edited by: G. Casassa

\section{References}

Azócar, G. F. and Brenning, A.: Hydrological and geomorphological significance of rock glaciers in the dry Andes, Chile $\left(27^{\circ}\right.$ $33^{\circ} \mathrm{S}$ ), Permafrost Periglac., 21(1), 42-53, 2010.

Bradley, R., Vuille, M., Diaz, H., and Vergara, W.: Climate change: Threats to water supplies in the tropical andes, Science, 312(5781), 1755-1756, 2006.

Casassa, G., López, P., Pouyaud, B., and Escobar, F.: Detection of changes in glacial run-off in alpine basins: examples from North America, the Alps, central Asia and the Andes, Hydrol. Process., 23(1), 31-41, 2008.

Cheesbrough, K., Edmunds, J., Tootle, G., Kerr, G., and Pochop, L.: Estimated wind river range (Wyoming, USA) glacier melt water contributions to agriculture, Remote Sensing, 1(4), 818828, 2009.

Chow, V.: Open-channel hydraulics, McGraw-Hill, 1959.

Comisión Regional del Medio Ambiente, Región de Atacama: Resolución RCA 024, Gobierno de Chile, http://seia.sea.gob. cl/externos/admin_seia_web/archivos/6316_2006_2_15_RE.pdf, 2006.

Corripio, J., Purves, R., and Rivera, A.: Modeling climate-change impacts on mountain glaciers and water resources in the Central Dry Andes, in: Darkening Peaks: Glacier Retreat, Science and Society, 126-135, University of California Press, USA, 2007.

Coudrain, A., Francou, B., and Kundzewicz, Z. W.: Glacier shrinkage in the Andes and consequences for water resources - Editorial, Hydrolog. Sci. J., 50(6), 925-932, 2005.

Direccion General de Aguas: Cuenca del Río Huasco, Technical report, Ministerio de Obras Publicas, Gobierno de Chile, 111 pp., 2004. 
Escobar, F., Casassa, G., and Pozo, V.: Variaciones de un glaciar de montaña en los Andes de Chile central en las últimas dos décadas, Bulletin de l'Institut français détudes andines, 24(3), 683-695, 1995.

Farr, T., Rosen, P., Caro, E., et al.: The Shuttle Radar Topography Mission, Rev. Geophys., 45(2), RG2004, doi:10.1029/2005RG000183, 2007.

Falvey, M. and Garreaud, R.: Regional cooling in a warming world: Recent temperature trends in the southeast Pacific and along the west coast of subtropical South America (1979-2006), J. Geophys. Res., 114(D4), D04102, doi:10.1029/2008JD010519, 2009.

Favier, V., Coudrain, A., Cadier, E., Francou, B., Ayabaca, E., Maisincho, L., Praderio, E., Villacis, M., and Wagnon, P.: Evidence of groundwater flow on Antizana ice-covered volcano, Ecuador, Hydrolog. Sci. J., 53(1), 278-291, doi:10.1623/hysj.53.1.278, 2008.

Favier, V., Falvey, M., Rabatel, A., Praderio, E., and López, D.: Interpreting discrepancies between discharge and precipitation in high-altitude area of Chile's Norte Chico region (26-32 S), Wat. Res. Res., 45(2), W02424, doi:10.1029/2008WR006802, 2009.

Fiebig-Wittmaack, M., Astudillo, O., Wheaton, E., Wittrock, V., Perez, C., and Ibacache, A.: Climatic trends and impact of climate change on agriculture in an arid Andean valley, Climatic Change, doi:10.1007/s10584-011-0200-z, accepted, 2010.

Fields, S.: The Price of Gold in Chile, Environ. Health Perspect., 114(9), A536-A539, 2006.

Francou, B., Vuille, M., Wagnon, P., Mendoza, J., and Sicart, J.E.: Tropical climate change recorded by a glacier in the central Andes during the last decades of the twentieth century: Chacaltaya, Bolivia, 16 S, J. Geophys. Res., 108(4154), 10-1029, doi:10.1029/2002JD002959, 2003.

Ginot, P., Kull, C., Schotterer, U., Schwikowski, M., and Gäggeler, H. W.: Glacier mass balance reconstruction by sublimation induced enrichment of chemical species on Cerro Tapado (Chilean Andes), Clim. Past, 2, 21-30, doi:10.5194/cp-2-21-2006, 2006.

Golder Associates, S. A.: Área de Pascua Lama, Tercera Región de Atacama - Recompilacíon de estudios de línea base actualizada de la criosfera, Technical report, Compañia Minera Nevada Ltda., Santiago de Chile, 2009.

Kuchment, L. S., Gelfan, A. N., and Demidov, V. N.: A distributed model of runoff generation in the permafrost regions, J. Hydrol., 240(1-2), 1-22, 2000.

Le Quesne, C., Acuña, C., Boninsegna, J. A., Rivera, A., and Barichivich, J.: Long-term glacier variations in the central andes of argentina and chile, inferred from historical records and treering reconstructed precipitation, Palaeogeogr. Palaeocl., 281(34), 334-344, 2009.

Leiva, J.: Recent fluctuations of the Argentinian glaciers, Global Planet. Change, 22(1-4), 169-177, 1999.

Lliboutry, L.: Le massif du Nevado Juncal (Andes de Santiago), Ses pénitents et ses glaciers., Rev. Geogr. Alp., 42(3), 465-495, 1954.

Lliboutry, L.: Glaciers of the Dry Andes, in: Satellite Image Atlas of Glaciers of the World: South America, United State Geological Survey Professional Paper, 1386-I, 1998.

Mark, B. and Seltzer, G.: Tropical glacier meltwater contribution to stream discharge: a case study in the Cordillera Blanca, Peru, J. Glaciol., 49(165), 271-281, 2003.
Montecinos, A., Díaz, A., and Aceituno, P.: Seasonal diagnostic and predictability of rainfall in subtropical south america based on tropical pacific sst., J. Climate, 13(4), 746-758, 2000.

Nicholson, L., Marin, J., Lopez, D., Rabatel, A., Bown, F., and Rivera, A.: Glacier inventory of the upper Huasco valley, Norte Chico, Chile: glacier characteristics, glacier change and comparison with central Chile, Ann. Glaciol., 50(53), 111-118, 2010.

NOAA National Weather Service, Center for Climate Prediction: Oceanic Nino Index, http://gcmd.nasa.gov/records/GCMD_ NOAA_NWS_CPC_ONI.html, 2010.

Oyarzún, J. and Oyarzún, R.: Sustainable development threats, inter-sector conflicts and environmental policy requirements in the arid, mining rich, northern Chile territory, Sustain. Dev., 19(4), 263-274, doi:10.1002/sd.441, 2011.

Pellicciotti, F., Burlando, P., and Van Vliet, K.: Recent trends in precipitation and streamflow in the Aconcagua River Basin, Central Chile, in: Glacier mass balance changes and meltwater discharge, Vol. 318, 17-38, International Association of Hydrological Sciences, Wallingford, United Kingdom, 2007.

Pellicciotti, F., Helbing, J., Rivera, A., Favier, V., Corripio, J., Araos, J., Sicart, J., and Carenzo, M.: A study of the energy balance and melt regime on Juncal Norte Glacier, semi-arid Andes of central Chile, using melt models of different complexity, Hydrol. Process., 22(19), 3980-3997, 2008.

Rabatel, A., Castebrunet, H., Favier, V., Nicholson, L., and Kinnard, C.: Glacier changes in the Pascua-Lama region, Chilean Andes $\left(29^{\circ} \mathrm{S}\right)$ : recent mass-balance and 50-year surface-area variations, The Cryosphere, 5, 1029-1041, doi:10.5194/tc-5-10292011, 2011.

Ramirez, E., Francou, B., Ribstein, P., Descloitres, M., Guerin, R., Mendoza, J., Gallaire, R., Pouyaud, B., and Jordan, E.: Small glaciers disappearing in the tropical Andes: a case-study in Bolivia: Glaciar Chacaltaya (16 S), J. Glaciol., 47(157), 187-194, 2001.

Ribstein, P., Tiriau, E., Francou, B., and Saravia, R.: Tropical climate and glacier hydrology: a case study in Bolivia, J. Hydrol., 165, 221-234, 1995.

Rivera, A., Acuna, C., Casassa, G., and Bown, F.: Use of remotely sensed and field data to estimate the contribution of Chilean glaciers to eustatic sea-level rise, Ann. Glaciol., 34(1), 367-372, 2002.

Schulz, O. and de Jong, C.: Snowmelt and sublimation: field experiments and modelling in the High Atlas Mountains of Morocco, Hydrol. Earth Syst. Sci., 8, 1076-1089, doi:10.5194/hess8-1076-2004, 2004.

Singh, P. and Singh, V. P.: Snow and glacier hydrology, Springer Netherlands, 2001.

Soruco, A., Vincent, C., Francou, B., Ribstein, P., Berger, T., Sicart, J. E., Wagnon, P., Arnaud, Y., Favier, V., and Lejeune, Y.: Mass balance of Glaciar Zongo, Bolivia, between 1956 and 2006, using glaciological, hydrological and geodetic methods, Ann. Glaciol., 50, 1-8, 2009.

Souvignet, M., Gaese, H., Ribbe, L., Kretschmer, N., and Oyarzún, R.: Statistical downscaling of precipitation and temperature in north-central Chile: an assessment of possible climate change impacts in an arid Andean watershed, Hydrolog. Sci. J., 55(1), 41-57, 2010.

Tague, C., Grant, G., Farrell, M., Choate, J., and Jefferson, A.: Deep groundwater mediates streamflow response to climate warming 
in the Oregon Cascades, Climatic Change, 86(1), 189-210, 2008.

Viviroli, D., Dürr, H., Messerli, B., Meybeck, M., and Weingartner, R.: Mountains of the world, water towers for humanity: Typology, mapping, and global significance, Water Resour. Res., 43(7), W07447, doi:10.1029/2006WR005653, 2007.

Vuille, M., Francou, B., Wagnon, P., Juen, I., Kaser, G., Mark, B., and Bradley, R.: Climate change and tropical Andean glaciers: Past, present and future, Earth-Sci. Rev., 89(3-4), 79-96, 2008.
Wagnon, P., Ribstein, P., Francou, B., and Pouyaud, B.: Annual cycle of energy balance of Zongo glacier, Cordillera Real, Bolivia, J. Geophys. Res., 104(D4), 3907-3923, 1999.

Winkler, M., Juen, I., Mölg, T., Wagnon, P., Gómez, J., and Kaser, G.: Measured and modelled sublimation on the tropical Glaciar Artesonraju, Perú, The Cryosphere, 3, 21-30, doi:10.5194/tc-321-2009, 2009. 